\title{
APLIKASI PERBAIKAN MANAJEMEN DALAM PERBENIHAN TIRAM MUTIARA (Pinctada Maxima)
}

\author{
Ida Komang Wardana, Sari Budi Moria Sembiring, dan Ketut Mahardika \\ Balai Besar Penelitian dan Pengembangan Budidaya Laut \\ Jl. Br. Gondol Kec. Gerokgak Kab. Buleleng, Kotak Pos 140, Singaraja, Bali 81101 \\ E-mail: genta1190@yahoo.co.id
}

\section{ABSTRAK}

Tiram mutiara merupakan salah satu komoditas andalan dalam budidaya perikanan laut di Indonesia yang sudah dikembangkan sejak tahun 1918 oleh pihak swasta, dan sudah memproduksi mutiara putih (south sea pearl) yang diakui masyarakat internasional berkualitas baik. Permasalahan utama yang dihadapi budidaya tiram mutiara adalah rendahnya produksi benih. Masa kritis dalam pemeliharaan larva yaitu pada umur 8-19 hari dengan tingkat sintasan (SR) cukup rendah dan masa kritis berikutnya pada saat pemeliharaan di laut, yang disebabkan oleh pengaruh lingkungan, manajemen pemeliharaan yang kurang tepat, dan kualitas benih itu sendiri. Berdasarkan hal tersebut maka teknik perkawinan silang dari induk yang berbeda nacre perlu diterapkan agar benih yang dihasilkan diharapkan lebih berkualitas dibandingkan dengan benih hasil perkawinan dari satu populasi. Data kegiatan perkawinan silang ini diharapkan dapat dijadikan sebagai pedoman dalam mendukung perkembangan budidaya tiram jenis Pinctada maxima ke depan terutama dalam hal penyediaan benih yang berkualitas baik. Perbaikan yang difokuskan dalam kegiatan ini antara lain dalam hal pemberian pakan awal larva, peningkatan SR sampai tahap yuwana dan penanganan setelah benih ditebar di laut. Tujuan dari penulisan ini adalah untuk menginformasikan beberapa perbaikan pemeliharaan benih kepada para pembudidaya tiram mutiara. Hasil kegiatan ini menunjukkan bahwa perkawinan silang tiram mutiara dari dua populasi berbeda dapat memperbaiki sintasan, keragaan morfologi benih, dan akan sangat membantu bagi pembudidaya tiram mutiara dalam penyediaan benih yang berkualitas baik sebagai calon indukan penghasil mutiara.

KATA KUNCI : perbaikan perbenihan, tiram mutiara (Pinctada maxima)

\section{PENDAHULUAN}

Indonesia merupakan negara kepulauan dengan tipe perairan yang beragam dan secara garis besar memiliki potensi untuk pengembangan budidaya laut, khususnya tiram mutiara (Pinctada maxima) dan abalon sebesar 62.040 ha, namun pemanfaatannya hingga saat sekarang baru sebesar 1\%(Hamzah, 2007). Tiram mutiara merupakan salah satu komoditas andalan dalam budidaya perikanan laut di Indonesia yang sudah dikembangkan sejak tahun 1918 oleh pihak swasta, dan sudah memproduksi mutiara putih (south sea pearl) yang diakui masyarakat internasional berkualitas baik. Permasalahan utama yang dihadapi budidaya tiram mutiara adalah rendahnya produksi benih. Masa kritis dalam pemeliharaan larva yaitu pada umur 8-19 hari dengan tingkat sintasan (SR) cukup rendah yaitu berkisar 1\%-3\%. (Supii et al., 2009). Masa kritis berikutnya yaitu pada saat pemeliharaan di laut, yang disebabkan oleh pengaruh lingkungan, manajemen pemeliharaan yang kurang tepat, dan kualitas benih tersebut. Beberapa faktor penyebab penurunan kualitas tiram mutiara antara lain; kondisi perairan yang kurang baik terutama tingkat kecerahan dan adanya bahan pencemar, serta kemungkinan penurunan keragaan genetik (Susilowati et al., 2003). Studi keragaan genetik tiram mutiara sudah banyak dilakukan tetapi belum diterapkan secara nyata oleh praktisi pembudidaya. Untuk mengatasi hal tersebut di atas, dibutuhkan upaya perbaikan dalam hal pemeliharaan benih dan penggunaan induk sebagai penghasil benih. Mengingat pembudidaya tiram mutiara di Bali, Sumbawa, dan Bima, membutuhkan benih berukuran di atas $5 \mathrm{~cm}$ sebagai calon operasi, karena benih dengan ukuran tersebut, dianggap aman untuk dilakukan pembesaran lebih lanjut.

Di alam tiram mutiara diketahui ada yang memiliki warna nacre kuning dan putih, akan tetapi populasi tiram dengan nacre putih sangat jarang dibandingkan nacre 
kuning. Tiram dengan nacre kuning memiliki keunggulan dalam hal produksi benih, sementara nacre putih dicari mantelnya untuk digunakan sebagai saibo yang berpengaruh terhadap kualitas dan warna mutiara yang dihasilkan. Untuk menghindari eksploitasi berlebih dalam populasi, perbaikan manajemen dalam budidaya perbenihan sangat perlu dilakukan. Menurut Alfsen (1987), kegiatan budidaya merupakan salah satu manajemen pelestarian populasi dan salah satu upaya untuk menghasilkan stok induk yang unggul yaitu dengan melakukan proses seleksi dan hibridisasi. Berdasarkan hal tersebut maka teknik perkawinan silang dari induk yang berbeda nacre perlu diterapkan agar benih yang dihasilkan diharapkan lebih berkualitas dibandingkan dengan benih hasil perkawinan dari satu populasi. Data kegiatan perkawinan silang ini diharapkan sebagai pedoman dalam mendukung perkembangan budidaya tiram jenis Pinctada maxima ke depan terutama dalam hal penyediaan benih dengan kualitas yang baik. Perbaikan yang difokuskan dalam kegiatan ini antara lain dalam hal pemberian pakan awal larva, peningkatan SR sampai tahap yuwana, dan penanganan setelah benih ditebar di laut.

\section{Koleksi Induk Tiram Mutiara}

Distribusi tiram mutiara jenis Pinctada maxima menyebar secara luas di sepanjang pantai Utara Australia, Myanmar, Thailand, Indonesia, Filipina, dan Papua Nugini pada kedalaman sampai 80 meter (Martin, 2004). Secara umum di perairan Indonesia jenis tiram ini dapat ditemukan di Bali Selatan, Sumbawa (NTB), Karawang, Maluku, Sulawesi, dan Kepulauan Raja Ampat (Iran Jaya). Induk tiram mutiara yang dipijahkan pada kegiatan ini diperoleh dari perairan Bali Selatan dan perairan Maluku. Induk dengan nacre kuning lebih banyak diperoleh dari perairan Bali sedangkan nacre putih berasal dari perairan Maluku. Secara morfologi induk alam dari kedua perairan tersebut berbeda dari ukuran panjang cangkang luar badannya (Gambar 1). Induk yang sudah diperoleh diadaptasikan pada perairan sekitar BBPPBL Gondol dengan menempatkan induk pada pocket yang digantung pada kedalaman 4-5 meter. Tingkat kematangan induk diobservasi setiap 2-3 minggu sekali atau disesuaikan dengan musim pemijahan. Musim pemijahan di perairan Indonesia, berlangsung pada bulan Januari sampai
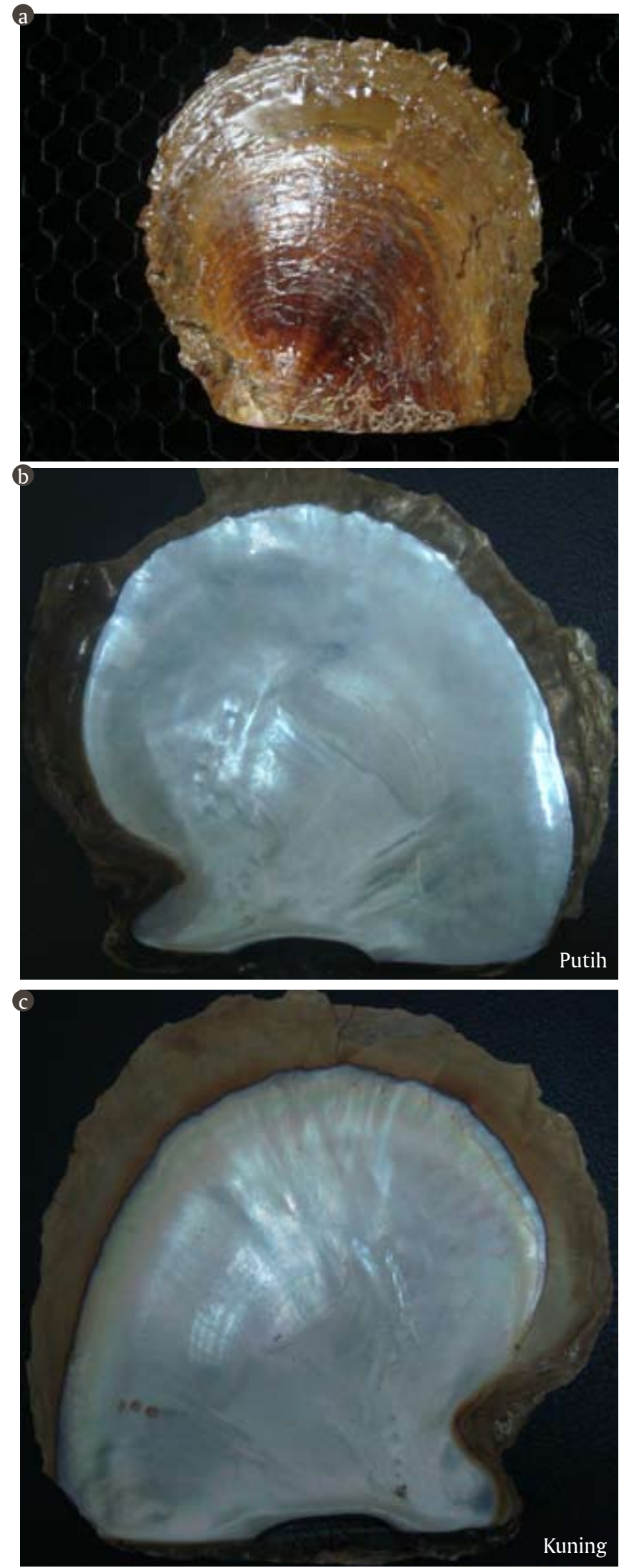

Gambar 1. Keragaan nacre induk alam tiram mutiara (Pinctada maxima) 
Maret dan pada akhir bulan September hingga Desember setiap tahunnya. Berdasarkan pengamatan di lapangan, pada bulan April sampai Agustus, induk tiram sangat jarang yang matang gonad, hal serupa juga dialami oleh para pembudidaya tiram mutiara yang ada di Bali.

\section{Penanganan Induk Tiram Mutiara Sebelum Pemijahan}

Proses pemijahan tiram mutiara antara nacre putih (Maluku) dan kuning (Bali) setelah masing-masing induk menunjukkan matang gonad sempurna, baik pada individu jantan maupun betina. Cangkang luar dari induk yang terpilih dibersihkan dari semua kotoran yang menempel, dibilas dengan air laut bersih atau air tawar. Induk yang sudah bersih cangkangnya diberi tanda dengan kode jantan atau betina sesuai dengan kondisi gonadnya. Induk dikering-anginkan selama 10-15 menit, sambil menyiapkan air laut bersih untuk media tempat pemijahan dalam bak fiber volume $100 \mathrm{~L}$ atau $200 \mathrm{~L}$. Rangsangan yang diberikan berupa kejut suhu dan sirkulasi air yang kontinu. Terjadinya pemijahan ditandai dengan keluarnya sel sperma terlebih dahulu lalu diikuti dengan pemijahan induk betina. Perkawinan silang yang diterapkan pada kegiatan ini seperti tertera pada Tabel 1.

Tabel 1. Metode perkawinan silang tiram mutiara

\begin{tabular}{|c|c|c|c|}
\hline \multirow{2}{*}{\multicolumn{2}{|c|}{$\begin{array}{l}\text { Perkawinan } \\
\text { silang }\end{array}$}} & \multicolumn{2}{|c|}{ Bali } \\
\hline & & Nacre putih & प Nacre kuning \\
\hline \multirow{2}{*}{ Maluku } & $\widehat{o}$ Nacre putih & & Benih F-1 \\
\hline & o Nacre kuning & Benih F-1 & \\
\hline
\end{tabular}

\section{Pemijahan Induk Tiram Mutiara}

Induk yang siap untuk dipijahkan, dimasukan ke dalam bak fiber tanpa menggunakan aerasi. Apabila selama 30 menit atau 60 menit pertama tidak terjadi respons pemijahan, air media diganti dengan membuang air media sebelumnya. Proses ini dapat berlangsung antara 4-5 kali sampai terjadi pemijahan. Setelah terjadi pemijahan, yang ditandai dengan keluarnya sperma terlebih dahulu dan berselang 10-15 menit sel telur mulai menyusul keluar. Apabila pada bak pemijahan warna air berubah keruh, induk bisa dipindahkan pada bak pemijahan yang baru untuk menampung sel sperma dan sel telur yang masih tersisa, hal ini dilakukan untuk mengurangi banyaknya jumlah sperma yang dapat memengaruhi proses pembelahan. Sel telur dan sel sperma yang sudah tertampung pada bak pemijahan diinkubasi selama 60-90 menit tanpa aerasi, agar proses pembelahan berlangsung sempurna.

\section{Penetasan Telur dan Pemeliharaan Larva Tiram Mutiara}

Tahapan yang dilakukan dalam persiapan penetasan telur, yaitu penyiapan bak penetasan dan pemeliharaan larva dengan menggunakan bak fiber volume 500 liter. Setelah 90 menit masa inkubasi, telur yang sudah dibuahi dipanen dengan menggunakan saringan bertingkat (30, 50, $60,80,120 \mu \mathrm{m})$. Kemudian telur dibilas dengan air bersih, di-sampling untuk mengetahui jumlah telur yang dihasilkan lalu dipindahkan ke dalam bak penetasan. Penetasan telur dibutuhkan waktu \pm 12 jam dengan kondisi lingkungan yang stabil, terutama suhu dan kadar oksigen terlarutnya. Telur yang sudah menetas menjadi fase trokofor ditandai dengan gerakan memutar melayang ke permukaan, dapat diamati dengan menggunakan bantuan senter LED. Tiga hingga empat jam kemudian larva sudah memasuki stadia veliger (tahap D).

Pemeliharaan larva dalam bak fiber dilakukan dengan terlebih dahulu dikultur pakan alami 3 hari sebelum penebaran larva. Pakan alami terutama plankton jenis Isochrysis sp., Pavlova sp., Chaetoceros sp., dan Nannochloropsis sp. Pemeliharaan larva berlangsung selama 40-45 hari dalam hatcheri dan dominan dalam kondisi gelap. Larva umur D-1-D-17 hanya diberikan campuran plankton jenis Isochrysis sp. dan Pavlova sp. Metode pemberian pakan pada larva tahap awal perkembangan, hanya 2 jenis plankton merupakan perbaikan dari metode sebelumnya, biasanya pakan yang diberikan terdiri atas 4-5 jenis plankton dengan komposisi yang berbeda-beda. Setelah melewati stadia pediveliger, pakan alami jenis lain dapat ditambahkan dengan volume disesuaikan dengan kondisi dan umur larva. Stadia spat muda hingga yuwana dipelihara di laut dengan pemantauan dilakukan setiap 2-3 minggu sekali.

\section{Hasil Perkawinan Silang}

Perkawinan silang tiram mutiara antar dua populasi (Bali dan Maluku) dapat dilakukan dengan hasil yang cukup baik. Berdasarkan hasil yang diperoleh (Tabel 2), 
Tabel 2. Jumlah telur, larva, spat, dan sintasan tiram mutiara hasil perkawinan silang

\begin{tabular}{lcc}
\hline \multicolumn{1}{c}{ Parameter } & $\begin{array}{c}\text { Perkawinan silang nacre kuning } \\
\text { (Bali) X nacre putih (Maluku) }\end{array}$ & $\begin{array}{c}\text { Perkawinan silang nacre putih } \\
\text { (Bali) X nacre kuning (Maluku) }\end{array}$ \\
\hline Bulan memijah & Maret 2012 & Juni 2012 \\
Jumlah induk yang memijah & 3 × X 5 & 2 \% X 3 \\
Jumlah telur (butir) & 2.200 .000 & 2.700 .000 \\
Hatching rate (\%) & 81 & 3,7 \\
Jumlah larva D-1 (veliger) & 1.800 .000 & 100.000 \\
Sintasan stadia pediveliger (\%) & $65(1.160 .000)$ & $45(45.000)$ \\
Jumlah spat (ekor) & \pm 7.000 & \pm 1.800 \\
Sintasan 2 cm up (\%) & $18,6(1.300)$ & $61(1.100)$ \\
\hline
\end{tabular}

perkawinan antara tiram nacre kuning (Bali) dengan putih (Maluku) atau sebaliknya, menghasilkan keturunan pertama (F-1) dengan keragaan yang lebih baik. Pemijahan tersebut menghasilkan telur yang berkualitas baik dengan "hatching rate" (HR) berada pada nilai $3,7 \%$ dan $81 \%$. Pada tahap pediveliger sintasan (SR) dari benih yang dihasilkan cukup baik, yaitu sebesar $45 \%$ dan $65 \%$, kondisi tersebut sangat berbeda dengan perkawinan satu populasi yang memiliki kisaran antara 16\%-22\% (Supii et al., 2011). Perkembangan stadia larva dari tahap veliger sampai tahap spat, benih dari hasil perkawinan silang menunjukkan perbedaan waktu perubahan stadia, warna larva, dan warna cangkang mulai memasuki stadia spat. Waktu perubahan stadia dari veliger menjadi tahap umbo dan stadia berikutnya lebih cepat 2 hari dibandingkan dengan benih dari hasil perkawinan satu populasi. Sementara warna larva dari awal perkembangan biasanya berwarna merah cendrung berwarna putih kekuningan dan pada tahap spat didominasi dengan warna putih gelap. Setelah memasuki tahap spat muda warna cangkang luar terdiri atas beberapa komposisi warna yaitu kuning, hijau, hitam, coklat, dan abu-abu (Gambar 2).

Apabila dibandingkan dengan warna yuwana (1 bulan di laut) dengan ukuran cangkang 0,8-1,5 cm; sebagian besar benih menunjukkan pola warna yang sama dengan adanya warna hijau, hitam, dan coklat (Gambar 3). Terjadinya perbedaan warna pada tahap awal larva dan spat muda, kemungkinan disebabkan oleh perbedaan habitat dari induk alam yang digunakan dan karena pengaruh perkawinan silang. Akan tetapi setelah memasuki stadia yuwana menunjukkan
Tabel 3. Perkembangan stadia dari benih tiram mutiara hasil perkawinan silang

\begin{tabular}{ll}
\hline Peliger & D-1-D-6 \\
Umbo & D-7-D-16 \\
Pediveliger & D-17 \\
& \\
Plantigrade & D-19 \\
Postlarva & \\
Spat & D-24 \\
\hline
\end{tabular}

pola warna yang tidak berbeda karena proses pembesaran di laut pada perairan yang sama (Gambar 4). Pada kegiatan ini jenis pakan alami yang diberikan dari stadia veliger sampai spat (D-1 - D-45) berupa campuran dari mikroalga jenis Isocrysis sp., Pavlova sp., Chaetocheros sp., dan Nannochloropsis sp. Untuk perkembangan tahap awal (D-1-D-17) cukup baik diberikan pakan hanya berupa Isocrysis sp. dan Pavlova sp. dengan 


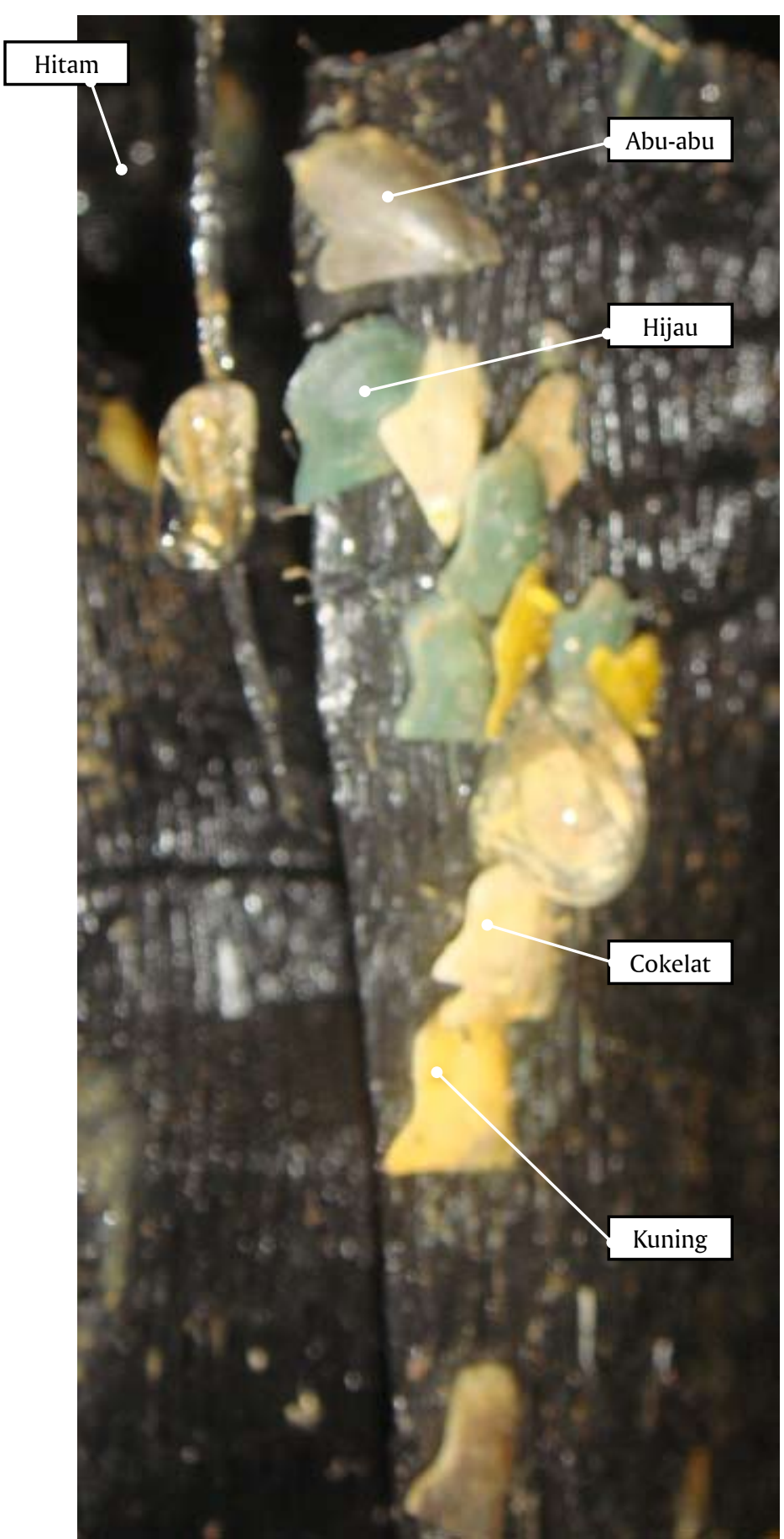

Gambar 2. Pola warna yang terbentuk pada spat muda

kepadatan $8.000 \mathrm{sel} / \mathrm{mL}$, karena kandungan nutrisi dari jenis pakan alami tersebut sudah memenuhi kebutuhan pakan untuk perkembangan larva tersebut dan benih lebih tahan setelah ditebar di laut. Setelah ditebar di perairan bebas, benih secara leluasa menyaring pakan yang tersedia pada perairan tempat benih dibesarkan.
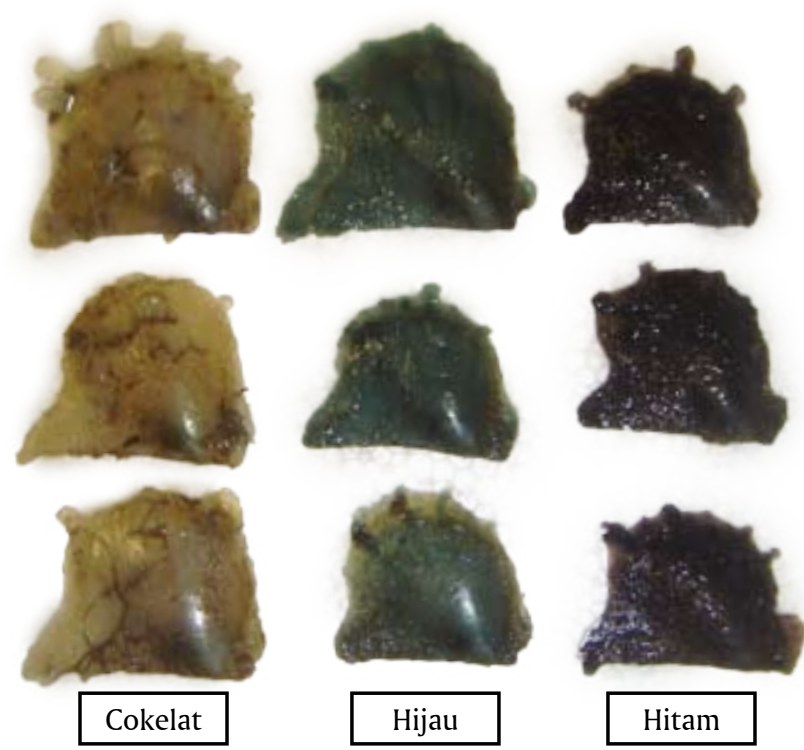

Gambar 3. Pola warna yang terbentuk pada yuwana muda

\section{Sintasan Benih}

Sintasan benih hasil perkawinan silang, berdasarkan pemantauan di lapangan menunjukkan nilai yang lebih baik dibandingkan dengan benih dari hasil perkawinan satu populasi. Hal tersebut dapat dilihat pada Tabel 4, yang menunjukkan perbedaan sintasan pada stadia pediveliger, spat, dan yuwana. Pada stadia pediveliger memberikan nilai di atas $40 \%$, setelah memasuki stadia spat, berdasarkan hasil sampling, jumlah benih yang berhasil menempel pada substrat relatif sedikit. Rendahnya tingkat sintasan benih dari stadia pediveliger menjadi spat, disebabkan oleh proses metamorfosis dari fase planktonik menjadi fase bentik (menempel) yang membutuhkan banyak energi, kemampuan adaptasi dari masing-masing individu tidak seragam dan pengaruh faktor lingkungan yang kurang stabil. Dhoe et al. (2001) dan Anonim (2004), yang menyebutkan bahwa faktor yang berpengaruh terhadap sintasan benih tiram mutiara antara lain: kondisi biofisik perairan (suhu, pH, DO, salinitas), adanya bahan pencemar, kedalaman, substrat dasar, kecerahan, adanya asupan air tawar, pola arus, dan tingkat kesuburan perairan. Sementara jika dilihat dari nilai sintasan pada benih umur 2 bulan pemeliharaan di laut pada kegiatan ini relatif tinggi. Hal tersebut kemungkinan dipengaruhi oleh penundaan pemotongan bisus pada benih ukuran 1-1,5 cm dan saat dilakukan sampling, kolektor hanya dibersihkan dari kotoran biofouling dan benih yang 

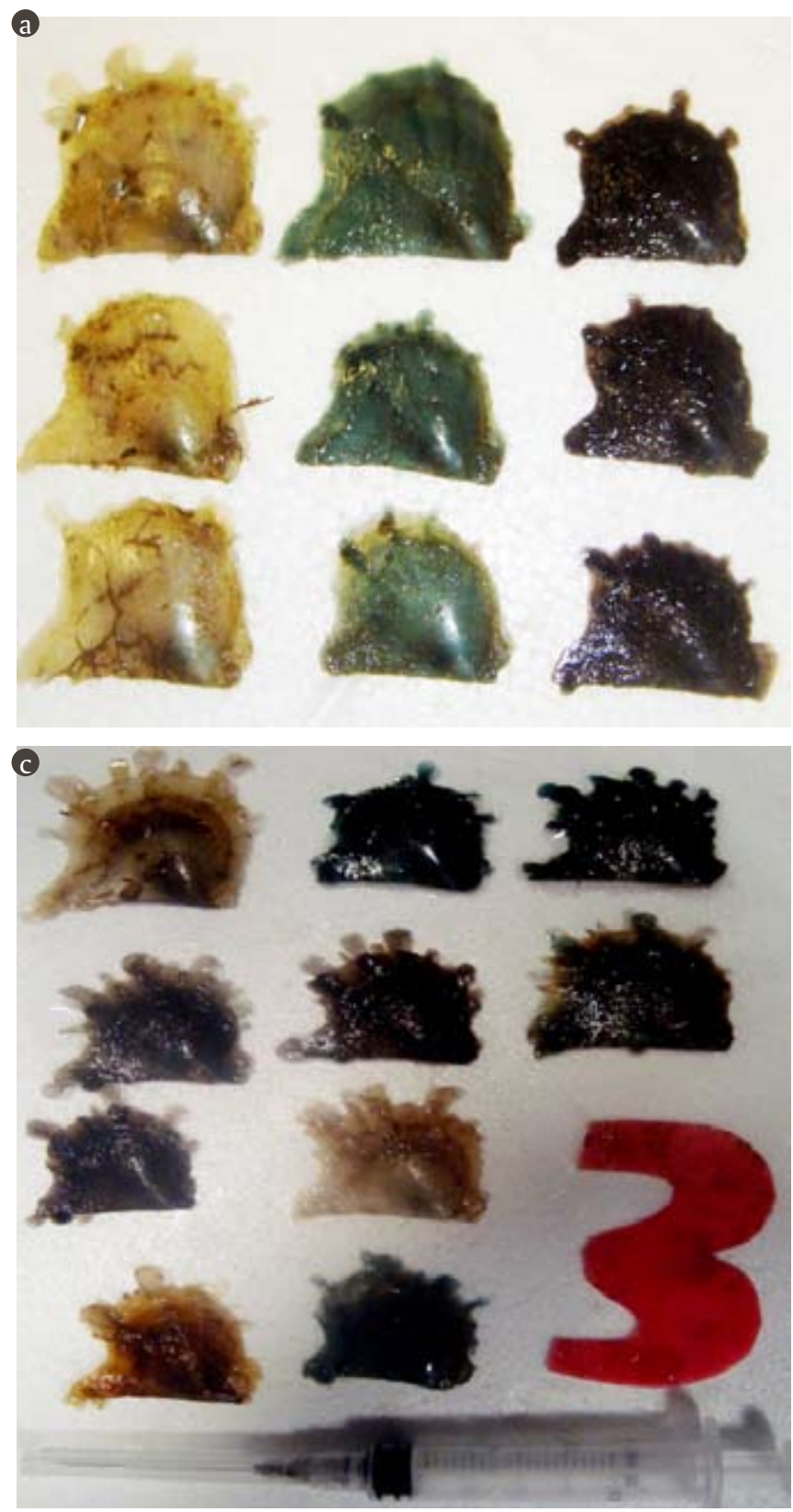

menempel agak padat pada satu sisi yang sama dilakukan penjarangan. Di samping itu, benih dengan ukuran cangkang kurang dari $4 \mathrm{~cm}$, ditempatkan pada kedalaman kurang dari $3 \mathrm{~m}$, yang bertujuan untuk mengurangi stres benih dari pemeliharaan di hatcheri ke perairan bebas dan untuk mempermudah benih menyaring pakan alami yang terkonsentrasi pada bagian permukaan perairan.

Berdasarkan nilai beberapa parameter yang diamati pada benih hasil perkawinan silang, secara deskriptif menunjukkan performa yang lebih baik dibandingkan dengan benih hasil perkawinan satu populasi (truebreed). Hal tersebut dapat terlihat pada nilai SR dan pertumbuhan

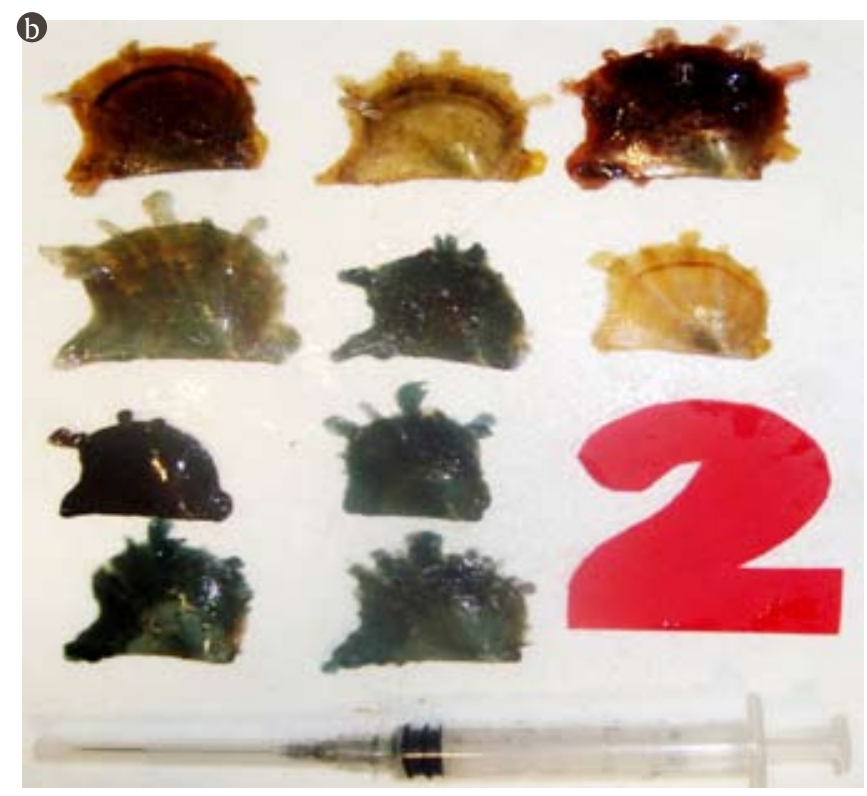

Gambar 4. Keragaan benih F-1 yang dihasilkan dari perkawinan silang

benih dari semua varietas cukup baik. Berdasarkan dari variasi ukuran badan dari benih hasil perkawinan silang menunjukkan variasi ukuran cangkang luar badan yang didominasi dengan ukuran besar. Benih yang berukuran besar (panjang cangkang > 2,5 cm) sebanyak 75\%, 20\% berukuran $2 \mathrm{~cm}$ (sedang) dan $5 \%$ memiliki ukuran $<1,5 \mathrm{~cm}$. Akan tetapi dari hasil pengamatan, benih dengan ukuran sedang pada observasi selanjutnya dapat tumbuh dengan baik yang ditandai dengan pertumbuhan kuku-kuku pada bagian permukaan cangkang luar benih (Gambar 5) dan benih-benih tersebut tetap dapat digunakan sebagai calon tiram untuk penyuntikan nukleus. Berdasarkan hal tersebut, dapat dikatakan bahwa perkawinan silang tiram mutiara dengan perbedaan warna nacre dari 2 populasi (Bali dan Maluku) memberikan pengaruh positif terhadap sintasan benih dan keragaan benih secara morfologi. Hal tersebut juga mendukung pernyataan Gjedrem (1993) dan Tave (1995) dalam Ath-thar et al. (2011), bahwa dengan melakukan hibridisasi antar 2 individu yang berbeda, maka secara tidak langsung akan mendapatkan keturunan yang lebih baik karena sifat heterosis yang ada pada banyak lokus termanfaatkan dengan baik.

Berhasilnya budidaya tiram mutiara secara nasional sangat ditentukan oleh adanya ketersediaan benih yang secara histori memiliki mutu dan kualitas baik. Berdasarkan dari pemaparan di atas, ada beberapa teknik yang dapat 
Tabel 4. Sintasan kelangsungan hidup pada stadia pediveliger, spat, dan benih berukuran di atas $2 \mathrm{~cm}$ pada tiram mutiara hasil perkawinan silang dan perkawinan satu populasi

\begin{tabular}{lccc}
\hline \multirow{2}{*}{ Parameter } & \multicolumn{3}{c}{ Sintasan (\%) } \\
\cline { 2 - 4 } & Pediveliger & Spat (D-45) & Benih 2 cm up. \\
\hline Perkawinan silang (K X P) & 65 & 6 & 8,5 \\
Perkawinan silang (P X K) & 45 & 18,6 & 61 \\
Perkawinan murni Bali & 22 & 0,1 & 1,8 \\
Perkawinan murni Maluku & 16 & 0,23 & 3,5 \\
\hline
\end{tabular}
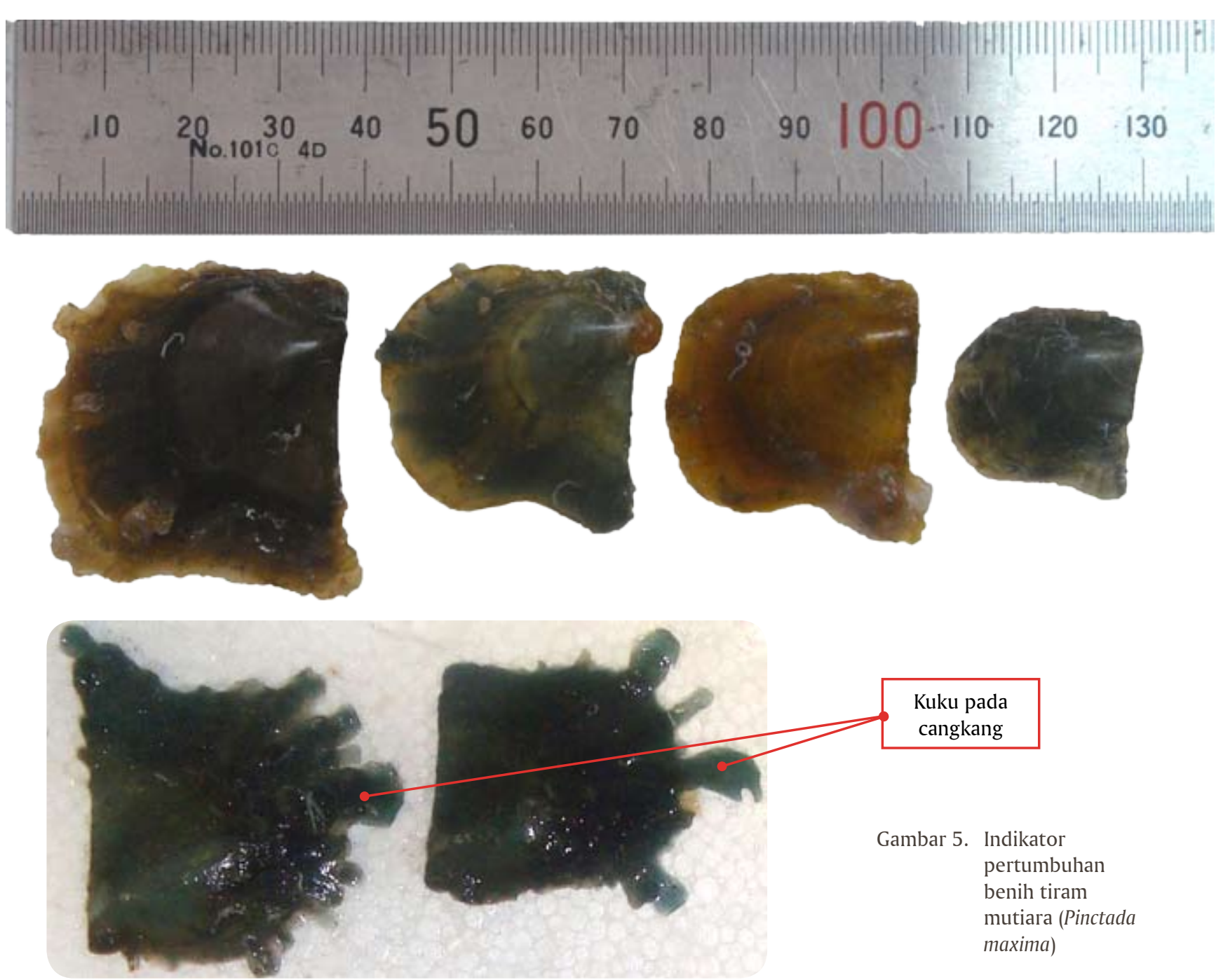

diterapkan dalam pemeliharaan benih sebelum benih berada dalam titik aman. Langkah tersebut antara lain:

1. Pilih induk dari beberapa populasi yang berbeda

2. Pemantauan tingkat kematangan gonad induk dilakukan pada bulan memijah dan rutin dicek setiap 2-3 minggu sekali

3. Pada tahap pemeliharaan larva di hatcheri, pada umur D-1-D-17 pakan alami yang diberikan, diupayakan merupakan campuran dari Isochrysis sp. dan Pavlova sp. dengan kepadatan tinggi dan konsentrasi pemberiannya disesuaikan dengan pertambahan umur larva

4. Pada tahap pediveliger (mulai mencari substrat), pakan alami jenis Chaetceros sp. dan Nannochloropsis sp. dapat mulai ditambahkan

5. Sintasan benih pada tahap pemeliharaan di laut dapat ditingkatkan dengan melakukan penundaan 
pemotogan bysus pada benih yang masih berukuran di bawah $2 \mathrm{~cm}$ dan meletakan pocket anakan pada kedalaman tidak lebih dari 3 meter (2-2,5m)

\section{PENUTUP}

Perkawinan silang tiram mutiara dari dua populasi berbeda dengan warna nacre kuning dan putih dapat memperbaiki sintasan dan keragaan morfologi benih tiram mutiara dan akan sangat membantu bagi pembudidaya tiram mutiara dalam penyediaan benih yang berkualitas baik, untuk dipersiapkan sebagai calon indukan penghasil mutiara.

Perbaikan teknik pemeliharaan benih dalam hatcheri dan saat pembesaran di laut yang memberikan pengaruh positif antara lain; pergantian air yang tepat, pemberian pakan awal yang berkualitas, penundaan pemotongan bysus, pengaturan kedalaman dan rutinitas pembersihan pocket dari penempelan biofouling.

\section{DAFTAR ACUAN}

Alfsen, C. 1987. Shellfish culture in France. SEADEAC, 96 pp.

Ath-thar, M.H.F., Prakoso, V.A., Nugroho, E., \& Gustiano, R. 2011. Heterosis, maternal, dan individual efek pada hibrida antara ikan mas Rajadanu, Majalaya, Subang, dan Kuningan.

Dhoe, S.B., Supriya, \& Juliaty, E. 2001. Biologi tiram mutiara. Pembenihan tiram mutiara (Pinctada maxima). Balai Budidaya Laut Lampung. Juknis, hlm. 6-12.

Anonims. 2004. Master plan program pengembangan kawasan budidaya laut. Direktorat Jenderal Perikanan
Budidaya. Departemen Kelautan dan Perikanan. Jakarta.

Hamzah, M.S. 2007. Variasi musiman beberapa parameter oseanografi, kaitannya dengan kisaran batas ambang toleransi kehidupan tiram mutiara (Pinctada maxima) dari beberapa lokasi di kawasan tengah Indonesia. Prosiding Seminar Nasional. Pusat Riset Perikanan Budidaya Badan Riset Kelautan dan Perikanan Departemen Kelautan dan Perikanan bekerja sama dengan Jurusan Ilmu Kelautan Fakultas Perikanan dan Ilmu Kelautan Universitas Diponegoro. Semarang.

Martin, C. 2004. Population strukture of the balck-lipped pearl oyster. Hohonu a Jurnal of Academic Writing, 2(2): 1-6.

Supii, A.I., Sudewi, \& Rusdi, I. 2009. Penelitian pembenihan tiram mutiara (Pinctada maxima) dengan manajemen pergantian air dan perbedaan ukuran tebar awal benih tiram mutiara di laut. Laporan Teknis BBRPBL Gondol, Bali.

Supii, A.I., Wardana, I.K., Sudewi., Priono, A., \& Haryanti. 2011. Pematangan gonad induk dan seleksi benih tiram mutiara (Pinctada maxima) dengan warna cangkang dalam putih. Laporan Hasil Penelitian. Balai Besar Penelitian dan Pengembangan Budidaya Laut Gondol, Bali. hlm. 79-90.

Susilowati, R., Sumantadinata, K., Soelistyowati, D., \& Sudradjat, A. 2009. Karakteristik genetik populasi tiram mutiara (Pinctada margaritifera) terkait dengan distribusi geografisnya di perairan Indonesia. J. Ris. Akuakultur, 4(1): 47-52. 